\title{
Jonson, Weston, and the Digbys: Patronage Relations in Some Later Poems
}

\author{
ROBERT C. EVANS
}

$\mathrm{T}$ he importance of patronage to Ben Jonson's non-dramatic poems is clear from even the most cursory glance at any collection of his works. Many if not most of the poems are explicitly addressed to patrons, and all the poems seem fundamentally conditioned by a culture grounded in patronage relations. But while patronage has often been discussed briefly in criticism of Jonson's poems, that discussion has sometimes seemed rather abstract. In fact, it is surprising how little we know about Jonson's flesh-and-blood patrons and about his day-to-day dealings with them. The brief biographical notes provided by most editions inevitably (and necessarily) stick to the most basic details. Even readers who attempt to track down further information will often face frustration: for many of Jonson's patrons only the barest biographical facts are readily available, and determined digging frequently turns up few more. But the more we know or can knowledgeably speculate about his dealing with his patrons, the better we can appreciate his purposes and achievements and the particular accomplishments and complex texture of his works. Information about the impact of patronage on Jonson's career is not so much "background" to the poems as it is essential to a richer appreciation of their peculiar artfulness. ${ }^{1}$

One of the most important patrons of Jonson's last decade was Richard Weston, for years a highly influential minister in the government of Charles I. More is known about Weston's life than about the lives of many of Jonson's other patrons, but the poems Jonson addressed to Weston have rarely been examined closely. Examining them seems worthwhile for a number of reasons. Not only can doing so provide new insights into the skill and success of these particular works, but it can also suggest significant aspects of Jonson's more general experiences and achievements as a patronage poet. The poems to Weston illustrate, for instance, the crucial importance of such intermediaries at a time when the poet's relations with the King and his status at court were less secure than they once had been. In fact, looking at Jonson's 
connection with Weston provides an opportunity to look more closely also at his relations with Sir Kenelm Digby, the editor of the 1640 Folio and another highly influential link in Jonson's connection to the Caroline aristocracy. One of the most intriguing poems of patronage Jonson ever wrote was addressed through Digby's wife to Digby, through Digby to Weston, and through Weston to the King and court. Examining the poem can not only give us a glimpse into the complex world of Stuart patronage, with its tangled networks and reciprocities, but can also suggest new facts about the circulation of (and relationships among) Jonson's poems themselves.

The poems to Weston and Digby also illustrate a number of other factors important to Jonson's more general experience as a patronage poet. For example, his willingness to identify himself so closely with Weston - a highly controversial figure - seems unusual for Jonson, and may suggest something about the changed nature of his status at the Caroline court and about the more general changes that had taken place between the court and the "country" during the Caroline period. The poems to Digby and Weston also exemplify how praise of superior patrons could be worked into celebrations of their social inferiors; how complex and uncertain Jonson's relations with his patrons could often be; how that complexity and ambivalence could be reflected in the detailed texture of his works; how various poems to the same patron could be linked in meaning and theme; how distrustful Jonson was of the growing importance of the visual arts at the Caroline court; how the intellectual habits and interests of his patrons may have influenced the kinds of poetry he wrote; how genuinely accomplished many of the poems of his last years are; and how effectively Jonson used his wit (in poems that sometimes discomfit readers who bring romantic and post-romantic critical assumptions to them) to promote himself and his work in the literary and social hierarchies of his day.

Wit was always one of Jonson's most potent resources for dealing with his patrons. John Aubrey reports that King James, on the spur of the moment, gave his poet $£ 100$ after Jonson delivered a jocular grace in doggerel verse before dinner one evening. ${ }^{2}$ Jonson seems to have used his wit most effectively when his need was greatest, especially in his final decade. Through it he was able to communicate some sense of the depth and desperation of his want while still seeming dignified and free of self-pity. When he was most powerless and weak, wit lent the impression that he still had power over 
himself, that he was still in control. It also gave him license to tease his patrons about their behavior without seeming strictly censorious. A humorous request for help, moreover, was likely to be more persuasive then persistent hectoring, and the potential rejection of a witty request was also easier to accept because less of one's public dignity or "face" has been risked. Jonson's typical approach is illustration by the poignantly clever "Epistle Mendicant" (Und. 71) he addressed sometime in the early 1630's "To the Right Honourable, the Lord high Treasurer of England," Richard Weston:

MY LORD;

POore wretched states, prest by extremities, Are faine to seeke for succours, and supplies Of Princes aides, or good mens Charities.

Disease, the Enemie, and his Ingineeres

Want, with the rest of his conceal'd compeeres,

Have cast a trench about mee, now, five yeares;

And made those strong approaches, by False braies,

Reduicts, Halfe-moones, Horne-workes, and such close wayes, The Muse not peepes out, one of hundred dayes;

But lyes block'd up, and straightned, narrow'd in, 10

Fix'd to the bed, and boords, unlike to win Health, or scarce breath, as she had never bin,

Unlesse some saving-Honour of the Crowne, Dare thinke it, to relieve, no lesse renowne, A Bed-rid Wit, then a besieged Towne.

Although Jonson claims that his muse is handicapped and incapacitated, the very skill with which he constructs and elaborates the poem's controlling analogy proves otherwise; his indirect description of his disabilities and anxieties renders the poem's success all the more impressive. When, in the final line - after having sustained the comparison of small things to great for such a span (itself an indication of strength and poetic power) - when after all this Jonson finally concedes that he is a small thing, merely "A Bed-rid Wit," the reader is unwilling to accept the description: the accomplishment of the poem refutes the intended diminishment. The implicit promise of renown that Jonson offers Weston and the King should they come to his aid seems all the more persuasive after the performance just ended: his protest of 
weakness testifies, paradoxically, to the real and enduring potency of his skills.

Jonson's decision to address his "Epistle Mendicant" to the Lord Treasurer was more significant than a first glance might suggest, for Weston's importance at court transcended his role as one of Charles's chief financial officers. Following Buckingham's assassination, Weston had risen to become the single most influential figure at Whitehall beneath the King, and although he never enjoyed the kind of intimacy with Charles that had given Buckingham such sway, his power was still enormous. His control of naval, Irish, financial, and foreign policies was predominant; only in matters of religion and the church did his arch-rival, Laud, exercise more leverage. Although he had been a respected member of the House of Commons while also serving King James as Chancellor of the Exchequer, after 1626 he came to be viewed - somewhat unfairly, it would seem - as one of Buckingham's lackeys. ${ }^{3}$

Certainly Weston was a determined supporter of the Crown; on the famous and fateful day of parliamentary disorder in March 1629, when members tried to resist the King's decree of adjournment, the House had rung with calls for Weston's impeachment. ${ }^{4}$ His appointment to the dual position of Lord Treasurer of England and Treasurer of the Exchequer in July 1628 had helped make him even more widely hated than he had previously been, for Weston took seriously the task of reducing by whatever means possible the Crown's bloated expenditure and debt. One means he hit upon - sharply cutting back the amount paid out in pensions - helped make him as unpopular at court as he was in the country at large. ${ }^{5}$ The fact that Weston himself was reaping huge profits from his office while trimming funds for others did not enhance his standing. "Although the Treasurer's official salary was only $£ 365$ a year," William Van Cleave Alexander reports, "he received many time that amount through fees and gratuities." According to G.E. Aylmer, "a Lord Treasurer who was watchful of his own interests but not technically corrupt was said to be able to make $£ 7000$ a year." Alexander estimates that Weston's profits from the office were "in the neighborhood of $£ 11,000$ or $£ 12,000$ yearly." Combined with the income he received from his real estate holding and from other sources, Weston in the early 1630's probably had at his disposal $£ 17,000$ to $£ 18,000$ per annum. ${ }^{6}$

Much of this money was spent as soon as it was received, for since 1627 Weston had been building a lavish new family estate in Surrey to advertise and strengthen the power he now enjoyed at court. Painters and other artisans had been put to work decorating the new mansion, which Weston apparently saw as the seat of the family he hoped would soon be raised to membership 
in the titled aristocracy. His creation in February 1633 as first Earl of Portland fulfilled this ambition, while the marriage of his son and heir the previous year to one of Charles's relatives must have bolstered his confidence that the King's favor would continue. Any such bolstering was welcome, for even a figure as powerful as Weston - or perhaps especially one as powerful as he - had good reason to wonder just how long his fortune would endure. Weston's potent enemies at court would have been delighted by his downfall and were not above attempting to engineer it. These included not only Laud, but even from time to time the Queen. Clarendon describes Weston as being

of an imperious nature, and nothinge wary in disobligeinge and provokinge other men, and had to much courage in offending and incensinge them, but after havinge offended and incensed them, he was of so unhappy a feminine temper that he was always in a terrible fright and apprehension of them. He had not that application, and submissyon and reverence for the Queene as might have been exspected from his wisdome and breedinge, and often crossed her praetences and desyres, with more rudeness than was naturall to him; yet he was impertinently sollicitous to know what her Majesty sayd of him in private, and what resentments shee had towards him; and when by some confidents (who had ther ends upon him from those offices) he was informed of some bitter expressions fallen from her Majesty, he was so exceedingly afflicted and tormented with the sense of it, that sometimes by passionate complaints and representations of the Kinge, sometimes by more dutifull addresses and expostulations with the Queene in bewaylinge his misfortunes, he frequently exposed himself, and left his condition worse then it was before.... He quickly lost the character of a bold, stoute, and magnanimous man, which he had bene long reputed to be, in worse tymes, and in his most prosperous season, fell under the reproch of beinge a man of bigg lookes, and of a meane and abjecte spiritt ... [7]

As long as Weston retained the confidence of the King, however, his enemies could not effectively hurt him, and at the time Jonson addressed his poem to Weston, the Lord Treasurer's power was great and still growing. With his large personal fortune he must have seemed as capable as anyone at court of relieving the poet's financial distress. But to Jonson, temporarily alienated from the King, Weston's ability to influence the "saving-Honour of the Crowne" (13) must have seemed even more significant. ${ }^{8}$ 


\section{II}

The year after he composed the "Epistle Mendicant," Jonson was presented with an opportunity to make the most of his own connection with Weston, and of Weston's connection with the King. Already in 1630 it had been rumored that Weston's son Hierome had become engaged to marry “one of the Blood-royal of Scotland, the Duke of Lennox's sister, and that with his Majesty's consent." But Hierome's wedding to Lady Frances Stuart did not in fact take place until 25 June 1632. Contemporary observers were astonished by the match, since it seemed in most respects "a very unequal one, the young duchess being very much above him in fortune and birth"; but Charles himself intervened to help bring the negotiations to a successful conclusion. Not only did he bestow a present of $£ 10,000$ upon Lady Frances, but he also showed the couple "extraordinary favour" in agreeing to give away the bride. ${ }^{9}$

Charles's avid interest in promoting the marriage could only serve to confirm and enhance Weston's power at court, but it must also have seemed to bode well for Hierome's future standing there. Weston had hopes that his son would be appointed Secretary of State or Master of the Court of Wards; already he had proven useful to the King on an important diplomatic mission, and he would shortly depart on another. The marriage and the poem it inspired thus offered Jonson the chance to help improve his standing in the eyes of the King and Queen, to strengthen his ties with the King's chief minister, to win the favor and good feelings of a young man whose own favor at court seemed sure to increase, and to display his artistic powers on the occasion of one of the most important social events of the year. ${ }^{10}$

As much a tribute to Weston as to the bride and groom themselves, Jonson's "EPITHALAMION" (Und. 75) also places particular emphasis on the example and role of Charles and his queen. Written in stanzas of eight lines, (a number associated with marriage in the Renaissance) and extending over twenty-four stanzas in all (perhaps to suggest the twenty-four hours of the day), the epithalamion addresses the sun, bidding it to stop on its progress in order to witness and lend glory to the wedding. Later, after the ceremony is completed and the newlywedded couple have retired, Jonson is at pains humorously to hasten the sun on its way, so that nightfall and the consummation of the marriage can occur. The address to the sun contributes to the poem's complexity of tone, for while the sun is regarded as a most fitting witness to so glorious an event, Jonson also implies that the sun's splendor seems secondary to the occasion he describes. His attitude toward the sun is alternately respectful and familiar, and helps the poem achieve its delicate 
balance of good humor and dignity, of wit and decorum, of public festiveness and private delight. Moreover, by figuratively stopping the sun's progress in his poem, Jonson helps call attention to the sense in which the epithalamion does precisely that - the sense in which it stops time, to celebrate, preserve, and commemorate a day whose importance the poem at once mirrors and creates.

Already in the first stanza Jonson indicates the central role Charles and Henrietta Maria will play in this celebration of another couple's marriage. The "EPITHALAMION" is as much a tribute to the "bountie" of the King and Queen (8), as much a glorification of their own wedded love, as it is a commemoration of Hierome's wedding day. In part Jonson's emphasis on the royal couple simply reflects the cult of married love that had already become a dominant motif of Caroline court culture; in part it reflects his natural impulse to address himself to his most important patrons. But the emphasis is hardly extraneous, not only because Jonson is careful to integrate it thematically with the rest of the work, but also because it was the very participation and interest of the King and Queen that helped make Hierome's wedding such a momentous and memorable event. By stressing the centrality of Charles and his wife, Jonson does not distract attention from the young couple, but instead thereby underscores their importance.

The centrality of the King and Queen to the "EPITHALAMION" is more than merely thematic, however. They are quite literally central to the poem or rather, they share that central position with Weston, the groom's father. The poem's two middle stanzas, the centre around which the rest of the work revolves, focus squarely on the grace, favor, and bounty their royal majesties show to Weston, and on the diligent and loyal service he returns. It is as if Jonson suggests that the gap of white space that separates the stanzas and divides the poem is bridged by the reciprocal devotions of the royal couple and their chief minister: what the King and Queen give to Weston in the way of "Dignitie, and Honour" (92)-including the dignity and honour they bestow by participating in this wedding - is returned to them by means of Weston's "Wisdome" and "Counsells deep" (98). The theme of union, which is so obviously crucial to the poem and which appears under such various guises as the union of man and wife, of France and England, of the earth and sun, and the physical union of the two sexes, here takes on still another dimension. In the same way that the love of Charles and Henrietta Maria sets an example for all other marriages, so the link the poem celebrates between Weston and the royal couple becomes a pattern, a standard of ideal reciprocity between ruler and subject, between patron and dependent. The literally central posi- 
tioning of Weston, Charles, and the Queen thus allows Jonson to underline through the form of the poem one of the chief implications of its content. At the same time, it also allows him to pay his patron Weston a particularly meaningful compliment, for although the concept of a "sovereign centre" was conventional in Renaissance aesthetics, in Jonson's poem the centre is shared between the sovereigns and their principal subject. ${ }^{11}$

Harmony is both the subject and the method of the epithalamion, and its importance is reinforced in different times as the poem proceeds. In the opening stanza, for instance, the balanced reference to the "bountie of a King, and beautie of his Queene" (8) helps emphasize alliteratively how the monarchs bring together and reconcile qualities that seem to have little in common; later Weston himself is praised, with a greater sense of paradox and through effective use of chiasmas, for having led "Mens Loves unto the Lawes, and Lawes to love the Crowne" (104). Similarly, in the stanzas just before the middle of the poem, the King and Queen are hailed as an exemplary bride and groom at the precise moment that Hierome and Frances make their entrance into the chapel. The syntax and subject references in the immediately succeeding lines are so complicated and obscure that it is sometimes difficult to tell at first when one couple and when the other is being referred to. When the sun is asked, for instance, whether in all his days he has seen "that Paire" who "became these Rites so well" (76), the reader can be forgiven for momentarily supposing that Hierome and Frances are intended. In the next line it becomes clear that Jonson means the King and Queen, but the ambiguity here and elsewhere seems deliberate rather than careless. Jonson emphasizes the connection between the royal couple and the newlyweds just as he emphasizes the connection between the Weston family's future and their future service to the Stuart dynasty and British state. The poem celebrates a harmony achieved (at many different levels) at a single moment of history, and then it projects that moment into the future, imagining the continuity of the Weston line, the endurance of the happy marriage, and Hierome's capacity to follow in his father's footsteps as a servant to the Crown. It reconciles youth and age, life and death, night and day, church and state, sexual desire and chaste thought ("The holy perfumes of the Mariage bed" [162]), and all the various elements of the court. In its final stanza, in words that epitomize the gentle humor and delicate decorum of the poem, Jonson wittily uses an economic metaphor involving public exchange to characterize the most private relations possible: 
They both are slip'd to Bed; Shut fast the Doore,

And let him freely gather Loves First-fruits,

Hee's Master of the Office; yet no more

Exacts then she is pleas'd to pay: no suits,

Strifes, murmures, or delay

Will last till day;

Night, and the sheetes will show

The longing couple, all that elder Lovers know.

This final image, with its stress on the perfect reconciliation of potentially opposed impulses, captures some of the flavor of the entire work. Although Hierome is credited with superior power and with the right to "Exact" what he desires, Jonson makes it clear that power is not abused. And more important, he makes it clear that there is no reason for its abuse, since what Hierome might exact, his wife is freely willing to bestow. This image of perfect concord - in which all conflict and opposition are overcome, in which service to one's superior is also identical with the perfect satisfaction of one's own desire - resonates so strongly because it echoes so much that came before it.

The whole epithalamion celebrates, claims to preserve, but (more significantly) attempts to foster and create this kind of unity and accord. The poem is so powerfully appealing precisely because the harmony it exalts is inevitably unstable and could exist perfectly only in a work of fiction. Like many of Jonson's celebratory works, the function of the poem is as much persuasive as festive. It attempts to conjure up (by making so attractive) the harmony it exalts. It betrays an awareness of the fragility of what it commemorates, and yet this awareness makes its commemoration all the more valuable and inviting. Jonson's willingness to admit details into the poem that implicitly or explicitly seem to contradict the harmony it praises is a tribute not only to the work's complex sophistication but also to its pragmatic usefulness. At one point he no sooner praises the bride's beauty than he admits that some spectators had come to rebuke the simplicity of her dress (43-44). Shortly after praising Weston, he refers bitingly to those who envy Weston's good fortune (118-20). Moments after the wedding ends, Jonson projects the marriage's survival in the face of "canker'd Jealousie" and "all corroding Arts" (135-36). He mentions prominently Bishop Laud's participation in the ceremony, although Laud and Weston in real life were often political rivals (132). ${ }^{12}$ And he beseeches long life for Weston at a time when Weston's health was in decline (181-84). The poem celebrates Weston's power while subtly indicating its inherent uncertainty. It exalts in his triumph over his 
enemies, but it never pretends that his enemies do not exist. It praises the Treasurer, but it also attempts to cultivate the favor of the King and of Hierome. And in so doing it promotes the interests of all three men as well as those of the poet. It is in some respects very much a political poem, in both the larger and smaller senses of that term. Far from being a passive record of a day's events, it is an attempt to make the meaning and symbolic significance of those events reverberate into the future. And in all these ways it calls attention to its own utility and accomplishment. One of Jonson's longest lyrics, the Weston epithalamion is also one of the most intriguing, evocative, and richly sophisticated works of his final period. Only a much more detailed analysis could hope to do it justice, but even these remarks may suggest that it is hardly the uninspired product of an old poet's weariness. ${ }^{14}$ Even in the final five years of his life, Jonson's poetic powers were far from extinguished. Viewing the epithalamion as a poem of patronage helps us appreciate more fully the complexity of its artistic achievement.

Jonson had more than the usual reasons for wanting to turn in an impressive performance when he came to write this work. His recent disappointments at court, and the news he had received that the King himself was at least momentarily displeased with him for attracting Inigo Jones (the royal architect) must have made him realize that Charles's favor could not be taken for granted. The epithalamion must have seemed an ideal patronage vehicle - not only providing an opportunity to regain the King's admiration and further enhance his standing with Weston, but also thereby repairing any damage done to his reputation and self-esteem. The work is an ambitious undertaking, but superbly carried off. Its success reflects credit on its patrons, and cannot have hurt Jonson's estimation in their eyes.

\section{III}

Jonson's concern around this time that Inigo Jones was besting him in the competition for court patronage and prestige seems to have been heightened by his more general misgivings about the growing popularity of the visual arts among the English aristocracy. The social status and financial success of painters grew as more and more of the English ruling class, imitating their Continental counterparts, took an increasing interest in painting. Often the aristocrats who seemed most friendly toward literature and who were the most conscientious patrons of poets were also the ones with the keenest interest in gathering, subsidizing, and displaying paintings. Art collecting and commissioning had become increasingly common activities in the 
last half of James's reign and in the early years under Charles. The Earl of Arundel - a close friend of Weston - set an example for many of his peers by amassing the first great private collection in England of painting, sculpture, and antiquities, and it was not long before he and Buckingham found themselves in competition for some of the same objets d'art. At first Buckingham appears to have begun collecting, more because it seemed the thing to do than because of any genuine aesthetic appreciation, but this in itself is of great historical interest. What is particularly fascinating about Buckingham, as Graham Parry has written, "is the cultural style adopted by a man who suddenly found himself equal with princes and endowed with bewildering amounts of money." 15 Much of that money, it would seem, found its way into the hands of visual artists, who could help to magnify - literally - their patron's image at court. By the time of his death the Duke seems to have developed a genuine taste for art, and his own example as a connoisseur was perhaps as important to the developing prestige of painting as the works he commissioned.

Charles himself seems to have had an even surer interest in and eye for art than the royal favorite. He had inherited collections of paintings from his mother and elder brother, and visiting dignitaries and aspiring courtiers presented him with numerous other works over the years. In no time his collection became one of the most renowned in Europe, and such continental masters as Van Dyck, Rubens, and Gentileschi found profitable employment at the English court. Given the monarch's passionate enthusiasm for the visual arts and for painting in particular, it would have been most unusual if Charles's courtiers did not also begin to cultivate and display such tastes. Poetry had always had to compete with painting for aristocratic attention, but by the early 1630 's the practical position of the poem in relation to the visual artist must have seemed in some ways far less secure than before.

In "An Epigram" to Richard Weston written around this time (Und. 77), Jonson emphasizes the superficiality of the visual arts and credits the Lord Treasurer with a taste too sophisticated to be seduced by them. But the compliment may well veil a more critical attitude, for as Jonson knew, Weston had spent or was spending large sums to decorate his new palace. To assist him, he had

procured the services of Balthasar Gerbier, a Dutchman who had once been associated with Buckingham and was now the accepted arbiter of fashion in the capital. Gerbier made suggestions concerning the design of mantelpieces and balustrades and recommended the hiring of crafts- 
men, painters, and sculptors. ... Gerbier also assisted with the layout of Weston's garden and served as an intermediary between him and Hubert Le Sueur, who was commissioned to cast an equestrian statue of Charles I. ... He was to receive at total of $£ 600$ for the statue, which was one of the highest prices paid for a work of art during the 1630's. [16]

Obviously this commission was motivated as much by political considerations as by aesthetic enthusiasm; Le Sueur was one of Charles's favorite artists, and for that reason alone it must have seemed sensible for Weston to patronize him. In 1629, the year before the contract for the statue, Weston had also commissioned a painting from Van Dyck, "which was ultimately presented as a New Year's gift to the King."17 At home and at court, then, Weston realized the practical value of the visual arts, but his friendship with Arundel suggests that his appreciation was genuine as well as pragmatic. Jonson's "Epigram" eloquently testifies to the importance Weston attached to art, while perhaps also tacitly criticizing that interest:

IF to my mind, great Lord, I had a state,

I would present you now with curious plate

Of Noremberg, or Turkie; hang your roomes

Not with the Arras, but the Persian Loomes.

I would, if price, or prayer could them get,

Send in, what or Romano, Tintoret,

Titian, or Raphael, Michael Angelo,

Have left in fame to equall, or out-goe

The old Greek-hands in picture, or in stone.

This I would doe, could I thinke Weston one

Catch'd with these Arts, wherein the Judge is wise

as farre as sense, and onely by the eyes.

But you I know, my Lord; and know you can

Discerne betweene a Statue, and a Man;

Can doe the things that Statues doe deserve,

And act the businesse, which they paint, or carve.

What you have studied are the arts of life;

To compose men, and manners; stint the strife

Of murmuring Subjects, make the Nations know

What worlds of blessings to good Kings they owe;

And mightiest Monarchs feele what large increase

Of sweets, and safeties, they possesse by Peace. 
These I looke up at, with a reverent eye,

And strike Religion in the standers-by;

Which, though I cannot as an Architect

In glorious Piles, or Pyramids erect

Unto your honour: I can tune in song

Aloud: and (happ'ly) it may last as long.

By opening the poem as he does, Jonson announces his good intentions while signaling less directly his financial need. If to his "mind" (his intention as well as his intellectual capacity) he had a commensurately impressive "state" (worldly condition; monetary fortune) he would present Weston with costly "plate" and "hand [his] roomes" with rich tapestries and paintings. He would ("if price, or prayer could them get") present Weston with works by the great painters and sculptors of the Italian Renaissance. The similarity in sound of "price" and "prayer" only emphasizes their semantic distinctions, while at the same time suggesting how the second word - and the idea it represents - can be debased and corrupted. "Prayer," which should signify self-abnegation and devotion to higher spiritual ideals, is here associated with the proud pursuit of selfish desire, with a need for the kind of worldly, superficial self-distinction the visual arts can provide. The Italian artists Jonson lists have achieved a kind of personal fame undreamt of by the "old Greek-hands" they have surpassed, whose very anonymity suggests how far they have been out-stripped, how much they have been forgotten.

Of course, as the poet slyly suggests, it was in fact Weston who enjoyed the kind of "state" about which Jonson could only surmise; it was Weston who had the money to spend - and who was spending it - on the sorts of items the opening lines detail. What might be called Jonson's "subjunctive generosity" may have been intended to prompt present favors from Weston by reminding this "great Lord" of the poet's slender means. Jonson's avowed inability to carry out his magnanimous wishes not only emphasizes his straitened circumstances but also indicates the high cost of visual art and the kinds of competition for it that existed. The poet's strategy seems to have been not only to make Weston feel a bit guilty about the sums he was spending, but also to cast doubt on the value he was getting for his money.

In fact, in a sudden shift that emphasizes poetry's dynamism in contrast to the static nature of painting and sculpture, Jonson in line 10 begins to take back and undo what he had seemed to promise in the epigram's opening. Using his own artistry to catch his readers by surprise, he claims that even if he were able to present Weston with gifts like those itemized in the opening 
lines, he would not do so, since Weston is incapable of being "Catch'd with these Arts, wherein the Judge is wise / As farre as sense, and onely by the eyes" (11-12). The verb "Catch'd" - metrically underscored - is significant, suggesting a sort of danger and deceptiveness about these crafty "Arts" (while perhaps also implying something sinister about the motives of some of their practitioners). Jonson credits Weston with the same kind of acute perceptiveness he himself demonstrates in assessing Weston's character: Jonson is able to discern the Treasurer's discernment. Both are well studied in the "arts of life." If Weston is willing to accept the poet's compliments to his acuity, then he must accept as well Jonson's assumptions about the visual arts. Jonson attributes both to himself and to his patron an insight that contrasts implicitly with the merely surface perception he claims those arts at once demand and display. ${ }^{18}$

The fact that Jonson's poem alludes to a similar work by Horace is only another means of testing the acuity of Weston and his other readers: only those sufficiently alert and perceptive will hear the echo. Yet for readers who do, the force of Jonson's poem will be magnified and its tact and power increased. The allusion to Horace helps protect the poem and sanction it, helps make his complaints against the visual arts seem less personal, more insulated from private envy, more enduringly archetypal. It helps suggest the extent to which the conflict between poetry and the visual arts is ageless and impersonal, even as it slyly suggests how Horace both achieved and bestowed a kind of personal fame not won by the artisans with whom he competed. The allusion here is hardly an example of sterile conventionality; instead, it illustrates how Jonson could apply and adapt the work of past writers to very real and specific contemporary situations. Any implied criticism of Weston or of rival artists issues not only from Jonson's pen but from Horace's, too.

Jonson's poem, however, is much more concerned to praise its patron than Horace's had been, just as its tone is much more insistently personal, much more obviously rooted in a deeply felt relationship. For Jonson, the visual arts are inadequate not only because of their superficiality, but because of their static quality, their inability to celebrate Weston's character as reflected in his deeds. Weston "Can doe the things that Statues doe deserve, / And act the businesse, which they paint, or carve" (14-15) - a formulation that implicitly points up the incapacity of statues, paintings, or carvings to imitate such doings, such actions, in the fullest sense. Only the lively art of poetry - in which words, like men, move through time - can do justice to Weston's accomplishments, which are actions informed by contemplation, by a "studied" familiarity with the "arts of life" (17). In fact, by describing 
some of Weston's accomplishments in the immediately ensuing lines, Jonson practices the powers he claims for his art, while depicting Weston himself as a kind of poet, able

To compose men, and manners; stint the strife

Of murmuring Subjects; make the Nations know What worlds of blessings to good Kings they owe:

And mightiest Monarchs feele what large increase

Of sweets, and safeties, they possess by Peace. [19]

The emphasis throughout this passage is on the verbs, an emphasis that underscores both Weston's deeds and poetry's capacity to render actions as painting cannot. As if to accentuate this point even further, Jonson next describes the same deeds as if they had been rendered visually, as if he were scrutinizing a painting or statue: "These I looke up at, with a reverent eye, / And strike Religion in the standers-by" (23-24). The effect of the lines is complicated; on the one hand they suggest that Weston's deeds are more impressive, in and of themselves, than any statue or painting of them could be; but the lines also imply the inability of a painting or statue to render a full and complete account of any deed that is truly great. Moreover, the syntactical ambiguity of the lines helps emphasize Jonson's potential role in enhancing Weston's reputation. Who or what, precisely, "strike[s] Religion in the standers-by"? When the lines are re-read, it seems clear that the reference is to "These" actions of Weston's. But for a moment the "strik[ing]" can seem to be done by Jonson - as indeed, on further reflection, in one sense it is. One intention of his poem, after all, is to pay striking tribute to Weston, and one of its competitive claims is that it can do this more effectively than the visual arts. The momentary syntactical confusion, which might at first seem merely clumsy (and which might thus exemplify the relative weakness of poetry), on second thought seems an instance of the meaningful ambiguity of Jonson's craft.

Although Weston's accomplishments have the potential impact of a powerful icon, the implied comparison only stresses the frozen inertness of the visual arts. It is hardly an accident that Jonson chooses in the last lines to contrast his "song" (a word itself suggesting fluidity and grace) not with painting or sculpture - which can at least suggest movement and vitality - but with the inescapable solidity of architecture. Yet the contrast has the further effect, paradoxically, or reminding us of the architectonic skill of Jonson's poem. 
The concluding reference to "an Architect" (25) seems a double blow specific and generic. In all probability the poem was written during Jonson's feud with the king's architect, Inigo Jones; but the last few lines suggest indirectly that no architect could do what Jonson modestly (if somewhat disingenuously) professes himself incapable of doing. His presentation of himself as a humble songster, modest about the capacities of his own art, comes with a certain irony at the end of a poem that so effectively argues the shortcomings of other artists and their media. But it also serves, perhaps, to balance the slight suggestion of satire in the reference to "glorious Piles, or Pyramids" (26). The poem was, after all, addressed to a man who was just then building or had recently completed the kind of prodigy house to which Jonson objected so strongly in his poem "To Penhurst" (For. 3).

The zenith of Weston's power and influence at Charles's court was reached in February 1632/33, when the King himself bestowed on the aging Treasurer the sword and mantle that signified his new rank as Earl of Portland. Jonson wrote an epigram for the occasion, but its purpose was perhaps as much to attack Weston's enemies at court and in the country as to celebrate the Earl himself. Weston by this time had become "the most controversial member of the government, with scores of enemies and detractors as well as friends and supporters." 20 Jonson's allegiance to the Earl - his willingness to risk making himself an enemy of Weston's foes - suggests not only that the Treasurer had already proven a valuable patron but also that Jonson expected his influence to continue. His elevation to the peerage, in fact, meant that his power and social prestige would no longer depend simply on his tenure in appointive office; and it also meant that Hierome was no longer simply the Treasurer's son but was also the prospective successor to his father's Earldom. ${ }^{21}$ Thus Jonson's provocative epigram "To the Envious" (Und. 73) must have also seemed a risk pragmatically worth taking. His willingness to align himself so distinctly with one court faction is a clear measure of his confidence in Weston's staying power in the face of all opposition:

LOoke up, thou seed of envie, and still bring

Thy faint, and narrow eyes, to reade the King

In his great Actions: view whom his large hand

Hath rais'd to be the Port unto his Land!

WESTON! That waking man! that Eye of State!

Who seldomme sleepes! whom bad men only hate!

Why doe I irritate, or stirre up thee,

Thou sluggish spawne, that canst, but wilt not see?

Feed on thy selfe for spight, and shew thy Kind: 
To vertue, and true worth, be ever blind.

Dreame thou could'st hurt it; but before thou wake

T<o>'effect it, feele, thou'ast made thine owne heart ake.

The epigram not only draw distinctions of character and image between Weston and his detractors - they with their squinting "narrow eyes" that "wilt not see" $(2 ; 8)$, he the personified "Eye of State" $(5)$ - but it also attempts to depict Weston's enemies as enemies of the King. Indeed, the description of the Lord Treasurer just quoted may have been consciously intended to allude to similar phrasing in the epithalamion composed less than a year earlier. There Weston was depicted - as he is depicted here (5) - as a "waking Man" (111), but in the epithalamion it was Charles who was associated with "That farre-all-seeing Eye" (109). Jonson chooses to emphasize the King's particular role in Weston's elevation, both for the obvious reason of self-interest and in order to make his rebuke of Weston's foes all the more authoritative. The Treasurer's enemies are counselled "to reade the Kinge / In his great Actions" (2-3), and although William Hunter glosses the verb "reade" as meaning to "learn from," 22 clearly another of the word's functions is to help call attention to the action of Jonson's poem itself, which facilitates the kind of "reading" it prescribes. Still, the point of the epigram is less to educate "the Envious" than to torment them. Jonson's emphasis on imperative verbs, prominently positioned and metrically stressed, gives the poem a kind of violent energy, while his open and avowed contempt for those he attacks contrasts nicely with their suppressed but seething spite. By the final line one may agree with him that Weston's antagonists have made their own hearts ache, but one recognizes as well the role his poem has played in exacerbating their vexation.

The full skill of the poem does not become obvious until one has a chance to re-read it. Then its underlying logic and patterns of imagery emerge into clearer view. The opening command, for instance - "LOoke up, thou seed of envie" - is variously effective. The first two words not only anticipate the later, more explicit emphasis on Weston's moral and social elevation, they also indicate already the debased status of those who envy him. It is as if Jonson has surprised a nest of vermin by turning over a rock; their "faint, and narrow eyes" wince at the light his poem casts upon them. He commands them (the very first word suggesting the authority the whole poem claims) to "LOoke up" - not only at the King and Weston but implicitly at the poet. The stature he openly ascribes to his patrons he tacitly assumes for himself. Just as the monarch and Earl can look down on the envious, so indeed does Jonson. 
The opening command is part of a pattern in the poem emphasizing upward movement - a pattern illustrated, most obviously, by the King's "rais[ing]" of Weston. But here the upward movement of the envious creatures' eyes only causes them to sink deeper into jealousy, torment, and discontent, whereas Weston's elevation supposedly makes him less vulnerable (even if more subject) to their hatred.

The creatures Jonson attacks are the "seed" of envy in several senses: they are its seat, its residence; they are its offspring; and they are its source, the infected sperm by which its virulence is spread. Jonson uses a word associated with life, vitality, and healthy procreation precisely for its ironic effect: these seeds represent not life but a kind of death, not generation but corruption, not propagation but a force that is ultimately self-destructive. The word implies the various ironies associated with these creatures, but it also suggests their smallness, their moral insignificance. Nonetheless, Jonson's contemptuous tone cannot quite mask his perception of the threat they pose.

Jonson's emphasis, in line 2, on their "eyes" is significant for several reasons. In the first place, the mention of their squinting eyes not only contrasts with the later reference to Weston as the wide-open "Eye of State" (5) but also links up with the description of him as a "waking man" (5). Indeed, the pattern of images involving sleep, wakefulness, dreaming, closing eyes, and eyes wide open helps organize the entire poem. The envious do squint, but they do not clearly see - unlike the Earl, whose vision serves the King; unlike the King, whose perception has led him to elevate Weston; and unlike the poet, whose insight allows him to appreciate and interpret for others his patrons' greatness. Weston's vision is comprehensive, all-embracing; the fact that this is so implies already that the envious are less a threat to him than they might be to a less observant man. Yet Weston's vision, like the poet's, is ostensibly focused less on his own interests than on the state's. The reference to the "narrow eyes" of the envious might at first suggest their acuity, but in fact Jonson implies how their sight is distorted - unlike his own, which allows him to perform the act of reading and interpretation he calls for in this poem. The King becomes a text within a text: both he and Jonson's poem raise and celebrate the Earl; both he and the poem demand the kind of scrutiny and appreciation the poem itself provides. By reading the King's actions and writing about them, Jonson makes it possible for others to understand them as clearly as he does. The poem offers itself for interpretation even as it interprets for others; it asks to be read, while offering its own reading of Weston and the King. 
Jonson claims that Charles has raised Weston to be the "Port unto his Land," but the poet's play on the Earl's title, which might at first seem somewhat strained, is not without its merits. Its very playfulness helps contribute to a somewhat light-hearted tone (suggesting strength and selfassurance) that balances both the sneering condemnation and the exclamatory praise that characterize the poem's phrasing elsewhere. Weston is the port the haven, the source of security and stability in a time of storms - to an England increasingly rocked by political, religious, and economic strife. ${ }^{23} \mathrm{Of}$ course, to Weston's enemies this claim must have seemed extremely ironic, since they viewed him as one cause of the nation's troubles, or at least as a major impediment to their solution. But Weston was a "port" in the second sense of being a crucial entry-point to the world of power and influence: anyone who sought access to the King and court would have to contend with him. ${ }^{24}$ The witty phrases, which at first may seem almost too witty, gains added point on reflection.

Jonson's description of Weston as a "waking man" - a phrase that suggests his alertness and vigor - may have seemed somewhat ironic in view of the Earl's declining health, but the phrase also suggests his powers of perception and observation and thus the danger he could still pose to enemies in general and to the envious in particular. ${ }^{25}$ The fact that he is someone "whom bad men only hate" (6) testifies both to his power and to their fear. Jonson's phrasing here - especially his placement of the adverb - is typical of a technical skill for which he is still given too little credit. "Only" glances both ways: it can modify the words that precede it as well as the one that follows. The fact that bad men can feel only hate for Weston exemplifies the stunted moral sense that helps to make them bad, and it also reinforces the earlier suggestion (in the reference to their "narrow eyes" [2]) of their constrictions and limitations. But Jonson's phrase can also be read to mean that only bad men hate Weston; good men (such as the King and Jonson) not only value him but exalt the goodness the Earl himself exhibits. Here as so often elsewhere in Jonson's poetry, a single word, exactly placed, resonates with finely tuned artistic and moral implications.

Jonson's stirring up and irritation of the envious "sluggish spawne" (7-8) not only looks back to the phrasing (and develops the implied situation) of the opening lines, it also emphasizes by contrast the constant wakefulness of Weston. The word "spawne" obviously recalls the "seed" mentioned earlier (although the connotations of the later word somehow seems less pleasant), while the adjective "sluggish" highlights by contrast not only the vigor of the Earl and King but also the vitality of Jonson's own poem, with its heavy use 
of active verbs, its emphasis on clipped monosyllables, its frequent brevity of phrase, and its sprinkled exclamations. The energy of the epigram contrasts with the moral sloth of those it indicts, whose only self-motivated action is an obstinate refusal to act, a perverse determination "not [to] see" Weston's worth. This willed blindness, paradoxically, allows others to see Weston's enemies for the corrupt breed they really are. Their refusal to see and appreciate Weston's true nature reveals their own natures (their own "King")' their blindness not only stands opposed to Weston's wakefulness but casts them into a darkness far blacker than the earlier references to their "narrow eyes" and sluggishness had suggested. Of course, Jonson's emphasis on the ways in which they reveal themselves de-emphasizes, on one level, the revelatory purpose of his poem, but on another level the phrasing insinuates the poet's role in "shew[ing]" the true natures of those he attacks. The poem's very existence exempts him from the charges of envy and ethical blindness he hurls at others.

Jonson's penultimate injunction - "Dreame thou could'st hurt it" (11) not only glances back, of course, at the already well-developed pattern of images involving sleep and waking, but also anticipates the final echo of that pattern in the last word of this line ("wake"). The verb "Dreame" implies that Weston's enemies can only fantasize about hurting him, that their power is so limited as to be almost laughable. This, of course, was hardly the case (as Weston well knew and as the epigram's existence suggests); it was in fact the reality of the threats Weston faced that may have made him appreciate a poem such as this. ${ }^{26}$ The ambiguity of Jonson's pronoun "it" is not without some point: the momentary confusion it causes forces the reader to puzzle out its referent more intently than might have been true if the word's meaning had been clearer. The word seems to look back to the earlier reference to Weston's "vertue, and true worth" (10), two nouns that Jonson treats as a single quality that transcends Weston, yet is embodied in him. To attack Weston, Jonson implies, is to assault Goodness itself.

The poem's final imperative verb - "feele" (12) - is most obviously addressed to the envious and calls attention to the pain they ostensibly have caused themselves. But the verb also helps call attention to the last effect (and to the over-all effectiveness) of Jonson's poem: what we as disinterested readers "feele" in the last line is the final twist of Jonson's irony. The poet here is cleverly modest: although he claims that the envious have made their "owne heart[s] ake," the causing of such pain has, of course, been one of the epigram's chief objectives all along. The pain the envious feel is heightened by their sense not only of Weston's but of Jonson's triumph, a triumph that 
becomes part of the subject of this poem, especially in its final line. Jonson obviously derives a double pleasure from his work: not only the joy of celebrating Weston but the glee of humiliating their mutual enemies. The epigram's sudden, final shift from the anticipated but illusory pain the envious hope to inflict on Weston to the reality of their own suffering underlines, again, the poem's vigor; the turn comes with a stabbing abruptness.

Only in the final line, in the penultimate word, does Jonson raise the possibility that he may have a single envious person in mind: he refers, after all, to a "heart," not "hearts." In retrospect, all the earlier words that could have been read as plurals could also have been read in a singular sense: "Envious"; "seed"; "Thy"; "eyes"; "thee"; "spawne"; "thou." Only "heart," almost at the very end of the poem unambiguously suggests a single target. Of course, the absent " $\mathrm{s}$ " may simply have been a slip; if not, it raises intriguing questions about whom Jonson may have had in mind. ${ }^{27}$ Perhaps he intended no one in particular, but meant simply to give the finale the force of a highly personal indictment, as if each individual reader should examine his own conscience to see if he might be guilty of envying the Lord Treasurer. Whatever the case, it seems highly appropriate that this poem so stuffed with vigorous verbs should end on one, and that that verb should be "ake" (12). This is a verb that suggests no outward action but merely an inward pain. The "sluggish spawne" will now feel nothing but a prolonged and vexing torment.

\section{IV}

Jonson had experienced vexations of his own in the months preceding the composition of the epigram just discussed. His play The Magnetic Lady, staged in the fall of 1632 , seems to have been more successful than the disastrous New Inn, but it still provoked derision from his antagonists. Inigo Jones was apparently present on opening night and found the play hilarious in ways Jonson had not intended, while Alexander Gill - the son of a man Jonson had attacked years earlier - unleashed a satire that elicited the old poet's answering scorn. ${ }^{28}$ Jonson's epigram celebrating King Charles's anniversary day in November did not prevent the queen from selecting another courtier to write the New Year's holiday masque - a decision that made Jonson more dependent than ever for patronage on such second-level figures as Weston and his son.

In an intriguing "Epigram To my MUSE, the Lady Digby, on her Husband, Sir KENELME DIGBY" (Und. 78), Jonson indicates the practical importance he attached to the approval of aristocrats like Weston. The poem 
also indicates how literary works could be circulated - and how literary reputation could be built - in a court culture dominated by patronage relations:

THo', happy Muse, thou know my Digby well,

Yet read him in these lines: He doth excell

In honour, courtesie, and all the parts

Court can call hers, or Man could call his Arts.

Hee's prudent, valiant, just, and temperate;

In him all vertue is beheld in State:

And he is built like some imperiall roome

For that to dwell in, and be still at home.

His brest is a brave Palace, a broad Street,

Where all heroique ample thoughts doe meet:

Where Nature such a large survey hat ta'en,

As other soules, to his, dwell in a Lane:

Witnesse his Action done at Scandero<0 >ne;

Upon my Birth-day the eleventh of June:

When the Apostle Barnabee the bright

Unto our yeare doth give the longest light.

In signe the Subject, and the Song will live,

Which I have vow'd posteritie to give.

Goe, Muse, in, and salute him. Say he be

Busie, or frowne at first; when he sees thee,

He will cleare up his forehead, thinke thou bring'st

Good Omen to him, in the note thou sing'st,

For he doth love my Verses, and will looke

Upon them, (next to Spenser's noble booke,)

And praise them too. $\mathrm{O}$ ! what a fame 't will be?

What reputation to my lines, and me,

When he shall read them at the Treasurer's bord,

The knowing Weston, and that learned Lord

Allowes them? Then, what copies shall be had,

What transcripts begg'd? how cry'd up, and how glad, 30

Wilt thou be, Muse, when this shall them befall?

Being sent to one, they will be read of all.

Digby was the son of Sir Everard Digby, a Gunpowder Plot conspirator who had been executed for his role in that attempted treason. Kenelm had remained a Catholic throughout his early years, and although he attended Oxford, his inability to endorse the Thirty-nine Articles meant that he could not be "admitted as a regular resident in a college." 29 Nonetheless he won recognition for his intelligence, and in 1617 was mentioned (along with Jonson) as a potential member of a proposed Royal Academy. Although that 
plan fell through, Digby's social and intellectual standing continued to grow. In 1621 he toured Italy, where he lectured, collected books, and met Van Dyke (whom he later patronized). In 1623 he was knighted and (around the same time) became a Gentleman to the Privy Council of the Prince. However, Buckingham's antagonism toward Digby's uncle, the Earl of Bristol, clouded the young man's prospects for significant further advancement. ${ }^{30}$

Another complicating factor was his romantic involvement with Venetia Stanley. They had fallen in love at an early age; his first trip to the Continent, in fact, seems to have been viewed by his mother as a means of separating him from Venetia. During his absence, reports may have reached her that Kenelm had died; for this reason or others, she apparently became involved with another courtier. Learning this, Digby determined to forget her, but a chance meeting after his return led, in 1625 , to a secret marriage. The hint of scandal that had become attached to Venetia's name was eventually dissipated by her conduct as Digby's wife. By all accounts she was very beautiful, but Digby seems to have admired her as much for her intelligence and understanding as for her physical attractiveness. ${ }^{31}$ Thus Jonson's praise of her as his muse is, for several reasons, more than a conventional compliment: it accords well with the image Digby himself liked to present of his wife; it bolsters Digby's efforts to rehabilitize her reputation; and it may in fact reflect Jonson's genuine regard for her intellectual accomplishment. Moreover, in a court that was placing increased stress on the ideal of married love, Jonson's celebration of the Digbys could only reflect well on all concerned. ${ }^{32}$

In the years following his marriage, Digby's own intellectual and social status continued to grow. Late in 1627 - realizing, perhaps, that Buckingham's ascendancy limited his prospects at court - he began to equip a small fleet for a voyage of plundering and privateering in the Mediterranean. Official papers commissioning the expedition authorized it as "tending to the service of the realm and the increase of [Digby's] knowledge." ${ }^{33}$ In fact the voyage was profitable on practically all counts. Digby's victory over a superior Venetian fleet "furnished the occasion of his earliest feat of public self-propaganda and patriotic posturing, namely 'Relation of a brave and resolute Sea-fight made by Sir Kenelm Digby...to his great Commendation and to the Honour of our English Nation" "34 The pamphlet's timing was superb, for after recent military set-backs under Buckingham, Digby's triumph "revived the country's international dignity a little." 35 Buckingham's assassination a short time later removed a potentially troublesome obstacle to Digby's further advancement, and indeed in the next few years - when Jonson's poem was written - his influence at court was at its height. Not long 
after his return to England he was appointed to a number of official posts, was awarded various monopolies, and was considered a possible candidate for Secretary of State. ${ }^{36}$ His friendship with Weston did not prevent him from maintaining close relations with Laud, at whose suggestion he donated many valuable books and manuscripts to the Bodleian Library in 1632.

His interest in literature went beyond book-collecting, however. During his Mediterranean expedition, Digby found time to compose not only a report about his famous battle but also a journal of the voyage; an English translation of Tasso's Aminta (now lost); the Loose Fantasies (his most famous creative work); and Observations on the 22 Stanza in the 9th Canto of the 2nd Book of Spenser's Faery Queene, the first sustained piece of Spenser criticism ever published. ${ }^{37}$ The Observations present a complicated numerological analysis of one of the most obscure passages in the whole of Spenser's epic. Digby considered the obscurity deliberate and claimed that "were nothing else extent of Spenser's writing, yet these few words would make me esteeme him no whit inferior to the most famous men that ever have been in any age: as giving evident testimony herein that he was thoroughly verst in the Mathematicall Sciences, in Philosophy, and in Divinity, to which this might serve for an ample Theme to make large Commentaries upon." 38 Digby's treatise is fascinating in its own right, but it also provides valuable evidence of the kind of assumptions and interests one of Jonson's patrons brought to his reading of literature.

It is even possible that the "lines" and "Verses" Jonson refers to in his poem to Digby were the lines and verses of the numerologically organized Weston epithalamion itself. By a happy coincidence, the date of Jonson's birth seems to have been the same date on which Digby won his famous battle with the Venetians, and by an even more remarkable coincidence, it was also this date - St. Barnabas's Day - on which Spenser, Digby's favorite poet, set his own Epithalamion. ${ }^{39}$ Jonson may in fact allude to Spenser's work in his poem to Digby, and it hardly seems inconceivable that the "Verses" he passed on to Digby (with the expectation that Digby in turn would pass them on to Weston) may have comprised his own recent effort in the genre Spenser had helped make famous. ${ }^{40}$ This assumption helps to explain the otherwise somewhat puzzling prominence Weston enjoys in a poem nominally addressed to Digby and his wife, and it also supports a fairly specific interpretation of Jonson's comment that Digby "doth love my Verses, and will looke / Upon the, (next to Spenser's noble booke,) / And praise them too" (23-25). If the "noble books" Jonson mentions here is The Faerie Queene, one is hard put to imagine which of Jonson's "Verses" would sustain such a 
comparison. It is possible that Jonson refers to his work as a whole, or to the edition of three of his uncollected plays - Bartholomew Fair, The Devil is an Ass, and The Staple of News - he was "struggling to bring out" in 1631 to raise much-needed money. ${ }^{41}$ Or perhaps he refers collectively to the poems, plays, and masques written since the publication of the first folio in 1616 . Eventually, it is true, all these works were turned over to Digby, who edited them for the posthumous 1640 folio, but contemporary evidence suggests that Digby did not receive the poet's writings en masse until "some short tyme before [Jonson's] decease" in 1637, while the present poem to Digby could have been written no later than the spring of $1633 .{ }^{42}$ It is also possible that the "Verses" Jonson mentions comprise the present poem, although Digby would have to have been quite an egotist indeed not only to have read lines commending himself at Weston's table but to "praise them too."

The simplest explanation may be that "Spenser's noble booke" refers to the small volume in which Spenser published his Epithalamion and Amoretti, and that the "Verses" of his own that Jonson mentions are the verses he wrote to celebrate the marriage of Weston's son. Digby, with his keen appreciation of both poets, would have been the ideal person to "read" (and point out the accomplishments and subtleties of) Jonson's lines "at the Treasurers bord." The poem's concluding reference to numerous "copies" and "transcripts" $(29 ; 30)$ reinforces the likelihood that Jonson has in mind a relatively short work (rather than all his "Verses" taken together), while the reference to Weston "Allow[ing]" the lines becomes, on this assumption, a pun - suggesting not only praise but sanction. There is no way to "prove" this supposition (only those immediately involved knew precisely which verses Jonson meant), but the possibility cannot be lightly dismissed. A poem exalting Digby and his wife would provide ideal accompaniment to one praising the recent marriage of the Lord Treasurer's son and heir.

Indeed, the poem's opening line, which refers to Venetia as "happy," implies that the chief source of her happiness is her marriage. In Jonson's writing, even such an apparently simple word can contain reserves of meaning: Venetia is "happy" first in the sense that she takes joy in her husband, secondly in the sense that she is fortunate to be married to such a man, and finally in the sense that both these circumstances contribute to her pleasant disposition. The intimacy between husband and wife celebrated in the poem's first lines is complemented by the poet's own close connection to his patroness; Venetia is a woman important to the lives of both Jonson and Digby, who are drawn even more closely together by the respect they share for her. Although the poem begins by commending Digby's "courtesie," the word 
also helps call attention to the same quality in Jonson's poem, and although the epigram is ostensibly addressed only to Venetia, it already implicitly addresses the wider audience anticipated at its close. The movement from its first line to its last word is a movement outward, from a tight focus on the happy threesome of poet, patron, and muse to a broader concern with the wider world of "all."

Here as in much of his poetry, Jonson effectively uses lists. The third line lists Digby's virtues as nouns, while the fifth lists them as adjectives. Both catalogues imply the plenitude of his qualities, the potentially inexhaustible tributes he might be paid. Although Digby had won renown for his martial courage, the fifth line emphasizes his qualities of restraint, reason, and judgment, as if to suggest (as Jonson does suggest elsewhere) that mere action does not a hero make. This, surely, is why he spends so much time describing Digby's character before mentioning his physical appearance, and why the description of his body is made to reflect the nature of his spirit and soul. Jonson repeatedly describes Digby in regal terms $(6-7 ; 9)$, not only to suggest his fitness for service at court but also to magnify his importance there. The poet credits his nature with having taken "a large survey" of Digby's being (11), but of course this claim also calls attention to the comprehensive vision of Digby presented by this epigram. It is, after all, the poem itself that so memorably explicates and expresses Digby's qualities - qualities ostensibly obvious to all. Even as he highlights Digby's virtues, Jonson claims that no highlighting is needed.

Yet Jonson's apparent modesty, his willingness to ascribe to "Nature" a central function of his poem, is immediately countered by a reference that at first might seem oddly intrusive - the allusion to his own birth (14). Initially it might seem overbearing to be reminded that Jonson was born on the same day as Digby's great victory, as if the two events were comparable in importance. On reflection, however, the reference seems more defensible. It not only allows Jonson to allude (as has already been suggested) to the date made famous in Spenser's "Epithalamion," but it more significantly suggests that somehow in the link between Digby and the two poets was preordained. Surely (Jonson seems to imply) it is no coincidence that he was born on the very day Digby would further ennoble - a day already full of meaning because of its associations with St. Barnaby and with the fullness of light. Surely (Jonson seems to suggest) his connection with Digby was fated; Venetia, his muse, is less the cause of this link than simply one of its instrument. It is as if Jonson has been destined all along to celebrate Digby someday in verse. Of course, in reality the completion of his projected poem on Digby's victory 
(implied in line 18) would depend less on some mystical fate than on the very practical support he received from his patron. Although Jonson makes his union with Digby seem destined, perhaps he also implies that its full realization would depend on Digby's continued pragmatic encouragement.

By suggesting that Venetia will actually read his verses aloud to her husband (and thus become a singer herself [22]), Jonson not only subtly directs her behavior but also implies a closer connection between poet and muse: it is one thing for a muse to inspire a poet's song, another still for her to sing it. When Jonson further implies that in a sense this singing is unnecessary since Digby already "love[s] my Verses" (23), he once again runs the risk of seeming boastful. But in part this claim merely pays tribute to the breadth of his patron's interests: despite being a great hero and a "Busie" man (20), he still finds time for beauty. Digby's interest in Spenser was apparently well-known, and his thoughtful appreciation of the earlier poet's writing would give his positive assessment of Jonson's work all the more credibility. Jonson's confidence in the worth of his own writings is balanced by his sense that having them read and approved by Digby (and then by Weston) would give them greater social luster. The acceptance of his works, he knew, would affect his own acceptance. Line 26 (with its heavy punctuation) implies an interesting distinction between the poet and his poems: it was not enough for the power of his lines to be acknowledged if that power did not help secure his own. Yet, at least ostensibly, the imprimatur of Digby and Weston will not so much add to the poems' value as merely make that value manifest to "all."

Just as Jonson will win prizes if his verses do, so, he suggests, will Venetia. The placement of the phrase "how cry'd up" (30) is suggestively ambiguous. It can look back to the preceding reference to the poems, implying that they will be celebrated, but it can also look forward to the succeeding reference to Venetia, implying that she too will be "cry'd up" (perhaps by others, perhaps by the poet in future verses) for her role in promoting him. One of Venetia's virtues as a muse is her lack of jealousy or envy; she will be genuinely and selflessly "glad" at Jonson's anticipated success (30). Yet his success, of course, will help ratify her own influence, both with her husband and in society at large. Being Jonson's muse when he wins his proper recognition will mean basking in the glow of his triumph. His future devotions to Venetia will be even more valuable to her if his present devotion wins wide social favor. The connections between poet, muse, patron, patron's patron, and chief patron wil all be more firmly cemented if Jonson's verses are "Allowe[d]" (29). The subjunctive gladness Jonson attributes to his muse in 
the poem's closing lines, the pleasure she takes in contemplating his success, looks back to her opening happiness in contemplating her husband. Her joy in the first connection anticipates the satisfaction she also feels in this one.

The poem's closing passage might make it seem as if Jonson is more concerned with exalting himself than with celebrating his patrons; his delight as he imagines the fame their approval will bring him seems at first almost tactlessly blunt, but the lines nonetheless do pay tribute to the pervasive influence the opinions of Weston and Digby enjoyed at Charles's court. At the same time, Jonson's apparent egotism is mitigated even further when one realizes that the last fourteen lines closely paraphrase an epigram by Martial. His self-concern seems less offensive when it becomes clear that he is playing variations on another man's theme. Weston and the Digbys are ennobled even more by being implicitly compared to Martial's patron, and in fact Jonson emphasizes the importance of his patrons far more than Martial does.

The intellectual qualities of both Kenelm Digby and his wife, combined with their financial resources and social prominence, must have made them seem ideal patrons in their own rights. And judging, among other things, by the number and nature of the poems they evoked and the role Digby played in publishing the posthumous 1640 collection of Jonson's works, their interest in the poet in the early 1630's must have been genuine, their encouragement sustained and sustaining. Jonson's "Epigram" to Venetia, however, is less important for what it reveals about his contacts with the Digbys than for what it intimates about the network of hierarchial relationships in which, as a practical poet, he had to operate. He passes his work to Venetia in the hope that she will communicate it to her husband, who might then read it in front of Weston, who might then promote the poet's reputation with those around and beneath him, but perhaps especially with those above. In few other poems does Jonson indicate quite so explicitly his awareness of the web of patronage connections or of the influence those contacts had on his status and reputation.

In nearly all his poems, however, to one degree or another, such awareness is implied. Jonson here implicitly concedes that it is not so much the value or success of the poem itself that matters as that value's public recognition by the socially influential. It will be less the work per se than Weston's reaction to it that will create the interest Jonson hopes for. Of course, this admission is in part simply another means of complimenting (and influencing) Weston; by attributing such power to him, it helps reinforce the mystique of the power he already holds. Yet the admission is also realistically frank. Jonson knew that not matter how great his merits were as an artist, his opportunities for artistic achievement depended considerably on the support 
he received from his patrons, and on the support they received from theirs. Every poem in some sense asserted his power, yet few poems express his ultimate dependence as fully or as clearly as the epigram to Venetia, his "MUSE". Behind the imaginative conceit of the poem's title stands the real woman and the other real figures on whose support its (and his) success would stand or fall. Like all of Jonson's poems to patrons, this one is a work interesting, in large part, for what it takes for granted.

\section{Auburn University at Montgomery}

\section{NOTES}

I thank the Huntington and Newberry Libraries for fellowships in support of my research.

1. For fuller discussion of these issues, see my study of Ben Jonson and the Poetics of Patronage (Lewisburg, Pa.: Bucknell University Press, 1989). My thinking about Jonson and patronage has been stimulated by the work of a number of previous writers, especially Richard Helgerson, Annabel Patterson, Don Wayne, Leah Marcus, and Stanley Fish. My book offers fuller acknowledgments and citations than I have space for here.

2. Ben Jonson, ed. C.H. Herford and Percy and Evelyn Simpson, 11 vols. (Oxford: Clarendon Press, 1925-52), 1: 180. All references to Jonson's works are to this edition, hereafter abbreviated " $\mathrm{H} \& \mathrm{~S}$ ". In quoting from Renaissance texts I have modernized $i / j$ and $u / v$.

3. See Michael Van Cleave Alexander, Charles I's Lord Treasurer (London: Macmillan, 1975), 130-31. On Weston, see also David Nichol Smith, Characters from the Histories and Memoirs of the Seventeenth Century (Oxford: Clarendon Press, 1918), 21-29, and Edward [Hyde], Earl of Clarendon, The History of the Rebellion and Civil Wars in England, ed. W. Dunn Macray, 6 vols. (Oxford: Clarendon Press, 1888), 1: 59-67).

4. For a superb account of the whole episode see Samuel R. Gardiner, History of England from the Accession of James I to the Outbreak of Civil War, 10 vols. (London: Longmans, 1883-84), 7: 67-79.

5. See Alexander, 161.

6. Alexander, 128-29 and 167-69; Aylmer, The King's Servants: The Civil Service Under Charles I, 1625-1642, 2nd ed. (New York: Columbia University Press, 1974), 203.

7. See Nichol Smith, 27-28. Alexander suggests (173) that Clarendon's harsh estimate may have been influenced by his regard for Laud, Weston's rival. However, the dispatches of various Venetian representatives at Charles's court also reflect the essential ambivalence of Weston's status and attitudes reported in Clarendon's account; see volumes 22 and 23 of the Calendar of State Papers... Venice, ed. Allen B. Hinds (London: HMSO, 1919-21) - hereafter cited as CSPV. These reports make it clear that although Weston enjoyed more influence than any other courtier, he also feared a fall. His preoccupation with the machinations of his rivals is a recurrent theme in the Venetian dispatches, and clearly he had good reason to worry. For instance, a 
report dated 27 July 1629 indicates the Queen's displeasure with Weston (CSPV 22: 142). Another, dated 7 September 1629, reports Weston's fears of falling and the likelihood of his eclipse (CSPV 22: 177). At one point a friendly courtier warned Weston that he would be held responsible for all that went wrong with a particular government policy, and the warning seems to have had some impact (CSPV 22: 184). A particularly interesting report indicates that, at least at one point, even Charles seems to have grown jealous of Weston's power and disdained seeming too dependent on him (CSPV 22: 204-05); yet, another report written just a few weeks later asserts that Weston was highly esteemed by Charles (CSPV 22: 218). This ambivalence is typical of the Venetian comments on Weston's fortunes during his years of greatest prosperity: even when (or perhaps especially when) his power seemed at its height, it never was (and never could be) entirely secure. The Lord Treasurer had too many natural antagonists and personal enemies for that to be the case. Thus various reports throughout the years of his preeminence indicate tensions with the Queen, who saw him as a rival for influence with Charles (CSPV 22: 450; 464); with the Puritans, who suspected him of Catholic sympathies (CSPV 22: 309); with the Catholics, who also distrusted him (Clarendon, 1: 63); with the French ambassador, who tried to stir up trouble for Weston in the English court (CSPV 22: 331; 510; 585); with various members of the Privy Council, who distrusted his power (CSPV 23: 220); with Archbishop Laud, one of Weston's most persistent foes (CSPV 23: 226), and with the people in general (CSPV 23: 315). The list of Weston's enemies could easily be extended; see Clarendon, 1: 62 .

Powerful though he was, Weston knew that he could not ignore his rivals; the Venetians frequently report his worries about his security and his attempts to ensure it (CSPV 22: $538,546 ; 598 ; 607)$. Evidence abounds that Charles favored Weston, and that as long as he did, the Treasurer's status was relatively secure (CSPV 22: 177; 281-20; 592; $623 ; 626 ; 637 ;$ CSPV 23: 80). Weston may have feared his rivals, but as long as he retained the King's support, his rivals also had reason to fear (CSPV 23: 87). Conflict with Weston or his kin might threaten ruin, even for powerful aristocrats (CSPV 23: 100). Much of the court's business inevitably passed through his hands (CSPV 22: 610). Moreover, Weston knew how to use his influence with the King to his own advantage and against his foes (CSPV 22: 464; 588). Yet when pretexts for attacking him arose, his rivals did not fail to exploit them (CSPV 23: 221-22). At times even Charles seemed to be growing distant (CSPV 23: 294-95). Usually, however, the King's support remained firm, helping Weston to weather several crises (CSPV 23: 223-24). Charles seems to have been genuinely afflicted by his old servant's death, and he assured Weston during his final illness that the interests of his family would be protected. Thus one of the last of the Venetian reports on Weston epitomizes their typical ambivalence, mentioning both the support he enjoyed and the protection he craved. Even in his last days he could not escape the anxiety about his power (now viewed as the prospective yet uncertain power of his heirs) that had bedevilled him throughout his life (CSPV 23: 350-51). For a humorous example of such anxiety, see Clarendon, 1: 66-67.

8. On Jonson's circumstances in his last decade see H\&S 1: 89-102; Marchette Chute, Ben Jonson of Westminster (New York: Dutton, 1953), 305-36; and David Riggs, Ben Jonson: A Life (Cambridge, Mass.: Harvard University Press, 1989), 295-350. After an early period of what Jonson seems to have interpreted as neglect in the first years of the new reign, he regained some of his old status at court, but then risked annoying Charles with his increasingly bitter attacks on his old rival, Inigo Jones, see Evans, 182-85. 
9. For the passages cited, see Alexander, 170.

10. Shirley and Davenant also wrote poems to celebrate the marriage; Davenant's final lines show his awareness that his contribution would inevitably be compared to those of other writers: "He that in strength of wishes, next shall trie, / $\mathrm{T}$ ' increase your blessings with his Poetry / May shew a fiercer Wit, and cleaner Art; / But not a more sincere, and eager Heart." Interestingly enough, Davenant's poem is addressed not to Hierome, but to his father; the poem praises the marriage as "A mixture of two Noble bloods" - language that must have appealed to the recently ennobled Weston. See The Works of Sir William Davenant (New York: Benjamin Blom, 1968), 1: 230-31. Shirley's first stanza also suggests his expectation that his poems would be compared with other gifts and tributes. See The Dramatic Works and Poems of James Shirley, ed. Alexander Dyce (London: J. Murray, 1833), 6: 438-39.

11. See Alastair Fowler, Triumphal Forms: Structural Patterns in Elizabethan Poetry (Cambridge: Cambridge University Press, 1970), 22-33.

12. Alexander reports (169) that Weston made "occasional friendly, albeit unsuccessful gestures" to Laud. One, a month before Hierome's wedding, also involved officiating at a religious service: Weston invited Laud to dedicate the newly-completed chapel of his new estate. Could Jonson's prominent reference to the Bishop be in any way related to such conciliatory motives?

13. The state of Weston's health may help to answer Annabel Patterson's question about why, through a classical allusion in the poem's last lines, "the question of decay was raised at all"; see Censorship and Interpretation: The Conditions of Writing and Reading in Early Modern England (Madison: University of Wisconsin Press, 1984), 138. By subtly reminding Weston of his frail health, Jonson also reminds him of the poem's ability to give him a kind of immortality, not only by celebrating him personally but also by helping him to cement the public status of his family. (On Weston's ambitions for his family, see, for instance, Clarendon, 1: 63.) Patterson implies some ambivalence in Jonson's attitude toward Weston (136-38).

14. "At some points," writes Virginia Tufte, "the tone suggests that the poet is weary at the idea of saying again all the things that are customarily said about weddings, but here and there Jonson is at his best." See The Poetry of Marriage: The Epithalamion in Europe and Its Development in England (Los Angeles: Tinnon-Brown, 1970), 217.

15. See The Golden age Restor'd: The Culture of the Stuart Court, 1603-42 (Manchester: Manchester University Press, 1981), 136. Parry valuably discusses Arundel and Buckingham as patrons (108-45).

16. Alexander, 169.

17. Alexander, 179.

18. Jonson's view of painting was probably not as uniformly negative as this poem suggests. For instance, a passage in the Discoveries proclaims that "Picture is the invention of Heaven: the most ancient, and most a kinne to Nature." Only a few lines earlier, however, Jonson writes that while both poetry and painting are concerned with imitation, "the Pen is more noble that the Pencill. For that can speake to the Understanding; the other, but to the Sense." And a little later he writes (in a passage inspired 
by Possevino) that "Picture tooke her faining from Poetry," and then lists painting's indebtedness to various other arts and sciences. See H\&S 8: 609-12. In "Ben Jonson: the Poet to the Painter" (Texas Studies in Literature and Language, 18 [1976-77]: 381-92), Mary Livingston argues that almost all of Jonson's comments about the visual arts include that they are incapable of adequately rendering universal truths (383).

When possible, we should try to place each of Jonson's pronouncements about the visual arts within its immediate context - especially its immediate patronage context - rather than generalizing very broadly about them. His expressed attitudes may have been affected by the seriousness of the threat he perceived at any given time from the visual arts (or, more precisely, from visual artists, such as Inigo Jones). On his disdain for the visual arts in his last years, see John Lemly's valuable article, "Masks and Self-Portraits in Jonson's Late Poetry," ELH 44 (1977): 248-66.

19. The $O E D$ records no use of the verb "compose" in connection with painting before 1655 , whereas the word's associations with writing seem much older (in fact, the $O E D$ cites one of Jonson's uses of it in this latter sense.)

In addition to linking the patron and the poet, the word "compose" (with its etymology of "bring together" and its associations with pacification) puns on Weston's political role and his vigorous support for a policy of peace. Ironically, Weston's actual effect on the English politics of his day was the opposite of "composing": his policies were decidedly controversial.

On an echo of Horace in "compose," and for other helpful comments on the poem's classical allusiveness, see Richard S. Peterson, Imitation and Praise in the Poems of Ben Jonson (New Haven: Yale University Press, 1980), 99-101.

20. Alexander, 172.

21. After his father's promotion, Hierome came to be called "Lord Weston." In addition to cultivating his attention in the "Epithalamion," Jonson in early 1633 addressed a very beautiful "Ode gratulatorie" to him to celebrate his return from an important mission abroad; see H\&S 8: 250-51. The poem's full title celebrates Hierome's own elevation by addressing him as " $\mathrm{L}$. Weston."

22. Complete Poetry of Ben Jonson (New York: Norton, 1963), 229n.

23. For other relevant meanings of "port," see the note in Ian Donaldson, ed., Ben Jonson (New York: Oxford University Press, 1985), 705.

24. On Weston's central role at court, see (for instance) CSPV 22: 608.

25. On other courtiers' fears of Weston, see (for instance) CSPV 23: 87.

26. During a high point in his unpopularity in 1634 , Weston sought to affect public opinion by having his dependents advertise his merits; see CSPV 23: 223-24.

27. One possibility is John Eliot, who (in one poem) had mocked Weston's patronage of Jonson and who (in another) may have had Weston in mind when he attacked him for flattering "e'en the worst of men" (H\&S 11: 406). Jonson replied to the first poem with spirited invective (H\&S 8: 408-09). Ironically, one of Weston's own fiercest opponents was the parliamentarian Sir John Eliot. 
28. Gill claims that "Inigo w[i]th laughter ther grewe fatt / That thear was Nothing worth the Laughing att." Significantly, Gill seems as much interested in embarrassing Jonson socially as in attacking his play (H\&S 11: 346-48). Jonson's responses was a small masterpiece of invective. Like Gill's poem, it seeks to embarrass its target socially, dredging up Gill's conviction a few years before for slandering the dead Buckingham, as well as Charles and James. Its ending epitomizes Jonson at his sardonic best: "A Rogue by Statute, censur'd to be whipt, / Cropt, branded, slit, neck-stockt; go, you are stript" (H\&S 8: 410-11). The last four words epitomize the poem's own effect.

Donald Lemen Clark, in John Milton at St. Paul's School (New York: Columbia University Press, 1948), recalls that Jonson had also been suspected of endorsing Buckingham's death, and suggests that his attack on Gill may have been partly designed to distance himself further from these allegations (96).

29. See R.T. Peterson, Sir Kenelm Digby: The Ornament of England, 1603-1665 (Cambridge, Mass.: Harvard University Press, 1956), 35. Also valuable on Digby's life is the preface to Vittorio Gabrieli's edition of Digby's Loose Fantasies (Roma: Edizioni di Storia e Letteratura, 1968).

30. R.T. Peterson, 54; 66.

31. See Gabrieli, 6.

32. R.T. Peterson (among others) argues that Digby wrote the Loose Fantasies to vindicate his wife's reputation (43). Gabrieli cautions that there is no evidence that Digby's manuscript ever circulated (xvii), but it seems difficult to believe that Digby wrote it with no intention of having it read.

33. Gabrieli, xxiii.

34. Gabrieli, xxv.

35. R.T. Peterson, 82.

36. R.T. Peterson, 83-84.

37. Gabrieli, xxiii.

38. See The Works of Edmund Spenser, ed. Edwin Greenlaw, et al. (Baltimore; Johns Hopkins Press, 1933), 2: 472.

39. On 11 June as Jonson's birthday, see Rosalind Miles, Ben Jonson: His Life and Work (London: Routledge and Kegan Paul, 1986), 280-81.

40. Ian Donaldson cautions that although the phrase "Barnabee the bright" (15) also occurs in Spenser's poem, it was traditional as well. See Ben Jonson, 707.

41. Chute, 326.

42. H\&S 11: 98. 